7-30-2021

\title{
Social Justice: An Outreach-extension Program
}

Gary B. Lapiz

Cebu Normal University, Cebu City, Philippines, lapizg@cnu.edu.ph

Amelia Girly L. Aranas

Cebu Technological University, Cebu City, Philippines,dr.glaranas@yahoo.com

See next page for additional authors

Follow this and additional works at: https://scholarhub.ui.ac.id/ajce

Part of the Education Policy Commons

\section{Recommended Citation}

Lapiz, Gary B.; Aranas, Amelia Girly L.; and Lagrosas, Anabelle C. (2021). Social Justice: An Outreachextension Program. ASEAN Journal of Community Engagement, 5(1), 183-209.

Available at: https://doi.org/10.7454/ajce.v5i1.1095

Creative Commons License

(c) (i) ()

This work is licensed under a Creative Commons Attribution-Share Alike 4.0 License.

This Research Article is brought to you for free and open access by the Universitas Indonesia at ASEAN Journal of Community Engagement. It has been accepted for inclusion in ASEAN Journal of Community Engagement. 


\title{
Social Justice: An Outreach-extension Program \\ Gary B. Lapiz ${ }^{1}$, Amelia Girly L. Aranas², Anabelle C. Lagrosas ${ }^{3}$ \\ ${ }^{1}$ Cebu Normal University, Cebu City, Philippines \\ ${ }^{2}$ Cebu Technological University, Cebu City, Philippines \\ ${ }^{3}$ DYMR-Radyo Pilipinas, Cebu Technological University, Cebu City, Philippines \\ *Correspondence email: lapiz@cnu.edu.ph
}

Received: July $2^{\text {nd }}, 2020$, Accepted: July $26^{\text {th }}, 2021$

\begin{abstract}
The impact of the COVID-19 pandemic on communities in the Philippines has affected in-person research on community engagement. This paper highlighted the necessity for continuous research on social justice during the pandemic in order to discover ways in which people can survive and thrive through the trying times. The paper is based on the extension program of the Cebu Normal University (CNU) Research Institute of Public Governance on Social Justice. It analyzed Kaangayan, the public education workshop on social justice's report to the Office of Extension Services and International Linkages. The report is based on an outreach extension service conducted in a barangay (community) in Cebu, Philippines. The pure "fishbowls" qualitative research method was employed to conduct the analysis, and participants were selected through an open invitation that was extended to the barangay. Based on the concluded activity, the report was prepared and submitted to the Office of Extension Services and International Linkages. Subsequently, all data was consolidated, processed, saturated, and finalized toward the qualitative results on policy analysis based on the technical/completion of outreach extension project and the results of the technical evaluation.
\end{abstract}

Keywords: policy framework vis-à-vis community engagement; pure "fishbowls qualitative method of research; barangay in Cebu; social justice/kaangayan; research-based outreach-extension program.

\section{Introduction}

The extension operations of the past four decades may be the largest institutional development effort the world has ever known (Anderson, Jock, Feder \& Gershon, 2003). Higher education institutions are mandated to render extension services together with instruction, research, and production. This is in recognition of the vital role that colleges and universities play in the development of communities, particularly the underprivileged and depressed communities (Office of the Vice-President for Research, Development and Extension Batangas State University, n.d.). In the Philippines, as stated in the CNU Manual on Extension Services and International Linkages (hereinafter called the Cebu Normal University Manual), state universities and colleges have been called upon by the national government to introduce programs that focus on national, regional, or local development (R.A. 7722). In response to 
this mandate, the CNU came up with a Manual on Extension Services and International Linkages (2019, January 04), which focuses on practicing, ensuring, and continuing the development and sustainability of learning for individuals and the wider society (Independent University, Bangladesh, n. d.).

This extension outreach program is a by-product of the authors' social justice research initiative. The aforementioned study demonstrated the government's effort in solving Philippine's political and socioeconomic problems in relation to social justice. This has resulted in a mismatch between the people's beliefs and expectations on how a government ought to operate based on the tenets of justice, and the government's attempt in solving Philippine's political and socioeconomic problems. In order to fill in the gap, it is important that citizens are educated on social justice and on the need for cooperation between the government and the people on social justice issues in order to improve the country's political and socioeconomic conditions.

The Department of Public Governance in coordination with the Research Institute of Public Governance initiated an outreach program titled, "Kaangayan: A Public Education on Social Justice" in order to comply with the universities' mandate in helping communities, by promoting civic education through social justice advocacy in order to encourage people to become model citizens who can contribute to nation-building. Thus, the outreach extension program on social justice initiated its program upon the request of the community leaders in conjunction with the $\mathrm{CNU}$ with the hope of strengthening cooperation among constituents and the Philippine Government - a move that is vital to the nation's progress (Lapiz, 2016). This extension initiative was aimed at establishing a research-based outreach extension program for the Department of RIPG about social justice and other selected provisions of the Cebu Normal University Manual.

It analysed Kaangayan, a public education workshop on social justice and submitted a training/completion report to the Extension Office based on the extension service conducted in a barangay in Cebu, Philippines. Although face-to-face research on community engagement is limited due to the impact of the COVID-19 pandemic in Philippine communities, this paper is focused on the importance of continuing research on social justice during the pandemic to ensure that such communities can survive and thrive. It is argued that the goal can only be achieved by starting on a small-scale, with micro-education in the various communities and eventually replicating the process in the wider society. This will encourage nation-building and promote cooperation between the people and the government. This is the essence of democracy and participatory governance- starting locally and progressively building a plural society. 


\subsection{The research paradigm}

Civic engagement refers to the ways in which citizens participate in community life in order to improve conditions for others or to help shape the community's future. This term has been used primarily in the context of younger people. But in the past few years, a new movement has emerged to promote greater civic engagement by older adults (Adler \& Goggin, 2005). In discussing civic engagement and community participation, four research paradigms are explored.

\subsubsection{The community engagement outreach continuum cased on extension policies}

Community engagement can take many forms and partners can include organized groups, agencies, institutions, or individuals. Collaborators may be engaged in health promotion, research, or policy making (McCloskey, McDonald, \& Cook, 2013). Engagement activities are defined along a continuum that analyses and represents non-academic stakeholder activities and interactions with academic researchers. Proposed continua begin with none to limited stakeholder inclusion and input into research and continue with descriptions of increasing presence, input, and participation in decision making. Despite some agreement in literature, there is need for the development of consistent terminology and definitions to promote the common understanding of strategies in engaged research (Thompson et al., 2021). According to the authors of the International Association of Public Participation, the Community Engagement Continuum as cited by McCloskey, McDonald, \& Cook (2013), the increasing level of community involvement, impact, trust, and communication flow, at the onset, exhibits an outreach that encompasses, (1) some community involvement; (2) communication flows from one community to another, to inform; (3) the coexistence of entities; and (4) the establishment of optimal communication channels for outreach.

According to Jennings (2018), and Jennings and Dawson (2015), community engagement research must recognize moral standing, interdependence, and power of all participants. It must exhibit empathy and mutual concern by balancing respective interests and creating awareness of the structural context of others, and grasp the interactions among individual agencies, institutional structures and community settings within which agencies operate, in order to advocate for benefits to traditionally underserved communities (El-Bassel et al., 2021).

Community engagement requires participation of community members in projects that address issues that concern them. Meaningful community participation extends beyond physical involvement to include generation of ideas, contributions to decision making, and sharing of responsibility. Among the factors that motivate people to participate are the desire 
to play an active role in bettering their own lives, fulfilling social or religious obligations, feeling a need for a sense of community, and wanting cash or in-kind rewards. Whatever the motivation, obtaining meaningful community participation and having a successful, sustained initiative, require that leaders respect, listen to, and learn from community members. An absence of mutual respect and co-learning can result in loss of time, trust, resources, and, most importantly, effectiveness (Henry, 2011; McCloskey, McDonald, \& Cook, 2013; Miller \& Shinn, 2005; Minkler, 2004).

According to conventional wisdom, education is supposed to increase civic skills and political knowledge that function as mechanisms that trigger participation (Persson, 2015). Knowledge has always played an important role in society. The role of education in upholding and spreading human rights is widely recognized, but knowledge about actual rights is limited (Quennerstedt, 2020). This holds true especially in relation to social justice advocacy in grassroot communities. Civic consciousness indicates the level of development of democratic consciousness, acceptance by citizens of democratic values, and experience of democratic relations, which determines social and legal collaboration between governmental authorities, civil society institutions, and individuals. It is defined as a special property of a socially active, self-sufficient personality, which is determined by the content of historical, civilizational, and socio-cultural development. The process of acquiring civic qualities is considered in a sociocultural context, when the demonstration of individual behavior is shown as a combination of subjective and objective factors. It is noted that the ontological existence of citizenship requires the development of qualities associated with political functions, for instance, the ability to be included in the system of power relations, the ability to collaborate with others for the sake of common goals, and the ability to place common interests above interests (Riezanova, 2020).

The theoretical roots of "empowerment" as a critical element of community engagement can be traced back to Brazilian educator Paolo Freire (Freire, 1970; Hur, 2006; McCloskey, McDonald, \& Cook, 2013). As articulated by Maton (2008), empowerment is "a group-based participatory, developmental process through which marginalized or oppressed individuals and groups gain greater control over their lives and environment, acquire valued resources and basic rights, and achieve important capacity building to improve health involves the development of sustainable skills, resources, and organizational structures in the affected community, 16 life goals and reduced societal marginalization." Ideally, empowerment is both a process and an outcome of community engagement (McCloskey, McDonald, \& Cook, 2013).

Social justice advocacy has been defined as organized efforts aimed at influencing public attitudes, policies, and laws to create a society guided by the vision of human rights, including 
political, economic, and social rights (Cohen, 2001 as cited by Nilsson, \& Schmidt, 2005). While this focus may translate into justice for future generations, there seems markedly less regard for justice for others in an intragenerational space (Mason, 2014).

As pointed out above, translating social justice to the grassroots on community engagement is a challenge. Key informants perceived justice in the Philippine political and socioeconomic environments more negatively than positively. This varies based on the benefit each one gets from the government. Since there are more negative perceptions, the government needs to put in more effort to strengthen its current political and socioeconomic programs that are vital for the nation's progress (Lapiz, 2016).

In understanding the context, there is a need to align extension and education to policies that will suit the needs of all governments toward civic participation including the Philippines as a member of the Association of Southeast Asian Nations (ASEAN) and the community of nations in the world.

Human rights education is a prominent concern of a number of international organizations and has been dominant on the United Nations' (UN) agenda for the past 20 years (Cassidy, Brunner \& Webster, 2014). The UN asserts that children and young people should have access to human rights education (HRE) and that schools are one of the key means through which HRE should be made available (Robinson, Phillips \& Quennerstedt, 2020. This claim should also be universal across citizens of all ages.

In September 2015, the General Assembly adopted the 2030 Agenda for Sustainable Development that includes 17 Sustainable Development Goals (SDGs). Building on the principle of "leaving no one behind," the new Agenda emphasizes a holistic approach to achieving sustainable development for all (un.org). This supports the claim that, "sustainable development, however, goes beyond liberal theories of justice in many respects" (Langhelle, 2000). The framework consists of 17 goals for environmental sustainability, social inclusion, economic development, peace, justice, good governance, and partnership: the main issues for the world population in the 21 st century.

Each goal has several targets that better define its aims. The total number of targets is 169 . The SDGs replace the Millennium Development Goals (MDGs), which expired in 2015 and were implemented over 15 years. The MDGs experience underscored the importance of updated datasets for achieving the goals. Indicators are the backbone for monitoring progress toward the SDGs at local, national, regional, and global levels. Sound indicators can make the SDGs and their targets instruments that help countries highlight their strengths and weaknesses and monitor their progress after implementation of policies. 
Goals and targets are interdependent and must be pursued together as far as possible. Achieving sustainable development has been hampered by trade-offs in favor of economic growth over social well-being and ecological viability, which may also affect the SDGs adopted by the member states of the United Nations. In contrast, the concept of inclusive development emphasizes the social, ecological, and political dimensions of development (Gupta \& Vegelin, 2016). Similarly, the Universal Declaration of Human Rights, reaffirmed at the recent World Conference on Human Rights, provides an authoritative definition of human rights standards, and is increasingly referred to as customary international law. It should provide an adequate starting point for HRE, which should facilitate a "human rights culture" (Wronka, 1994). This should serve as a basis for the adoption of human rights and social justice education in community engagement.

The establishment of the ASEAN Community in 2015 marked a milestone of progressive regionalization in the southeastern Asian region. The ASEAN Intergovernmental Commission on Human Rights and the ASEAN Commission on the Promotion and Protection of the Rights of Women and Children (ACWC) were designated as pivotal organs to strengthen the realization of the right to education as part of the rights guaranteed in the ASEAN Declaration of Human Rights. The ASEAN Political-Security and Socio-Cultural communities recognize the importance of human rights (Juwita, 2020). They focus on "One Vision. One Identity. One Community." The ASEAN community is a community of opportunities under three community pillars: Political-Security Community, Economic Community, and Socio-Cultural Community (ASEAN Studies Centre, 2018). By 2025, the ASEAN Socio-Cultural Community will be an organization that is inclusive, resilient and dynamic, and engages and benefits the people (asean.org).

The Philippine Development Plan (PDP) 2017-2022 is the first medium term plan to be anchored on the 0-10-point Socioeconomic Agenda and is geared toward the AmBisyon Natin 2040, which articulates the Filipino people's collective vision of a matatag, maginhawa, at panatag na buhay para sa lahat. It also takes into account the country's international commitments such as the 2030 SDGs (National Economic and Development Authority, 2017). Similar to the Philippine Development Plan (PDP) 2017-2022, the Central Visayas Regional Development Plan (RDP) 2017-2022 is anchored on the country's long-term vision (AmBisyon Natin 2040) of a stable, comfortable, and secure life (matatag, maginhawa, at panatag na buhay). It also takes into account the 0+10-point Socioeconomic Agenda of the Duterte Administration and the 2030 Sustainable Development Agenda adopted by the United Nations in 2015 (National Economic and Development Authority Region 7, 2018). 
Figure 1 serves as the theoretical framework that manifests four (4) parts, namely: Outreach in the Community Engagement Continuum as cited by McCloskey, McDonald, \& Cook (2013) vis-à-vis Extension Policies; Kaangayan as an outreach-extension program that provided as the basis for the completion and submission of the technical report; Enhancing Social Justice as an Advocacy through National Budget Circular (NBC 461) for the sustenance of the program; and The Program Development towards Contribution to Increasing Output per the Cebu Normal University's Mandate, Agenda, Strategic Directions and/or Goals.

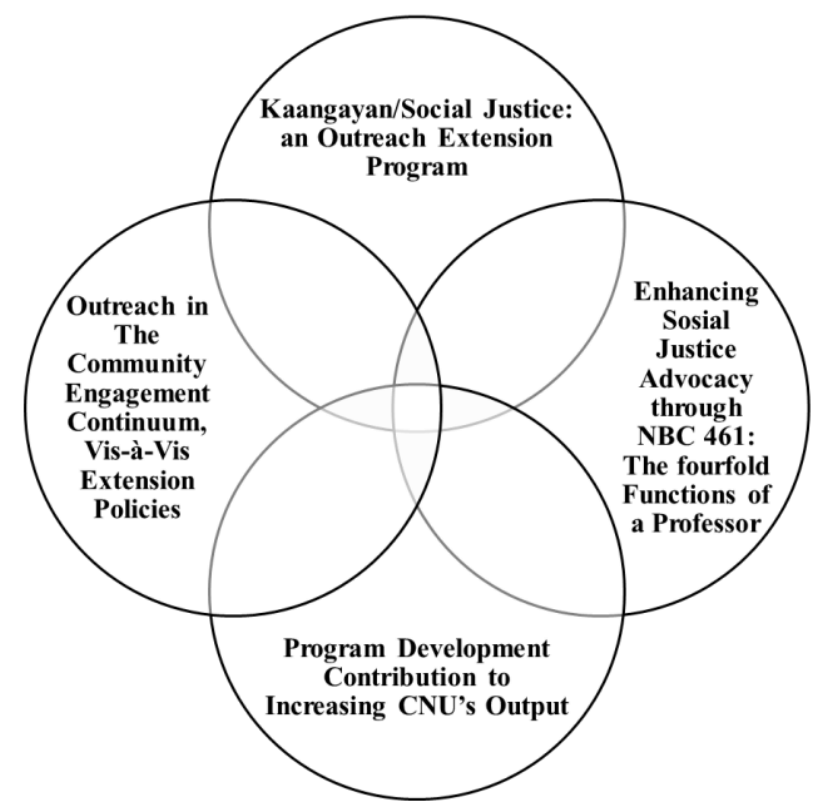

Figure 1. Kaangayan: An Outreach-Extension Paradigm

\subsubsection{Enhancing social justice advocacy through NBC 461: The fourfold functions of a professor}

The technical report showed that an extension that will add value to social justice advocacy and impact society should encompass instruction, production and research capabilities reflected under the National Budget Circular (NBC). This paper has exemplified social justice through research and extension. The next stage in the process is to expand the advocacy by teaching recipients in the classroom and disseminating information through seminars and training.

The growing demand for and debates about democratization and political participation from the majority of the citizenry, along with increased pressure from civil society, go beyond the legalistic definition of 'citizenship' to encompass the more multidimensional meanings of the concept, including justice, belonging, tolerance, and intercultural understanding. Teaching democratic citizenship can serve as the touchstone to guarantee social harmony, civic 
engagement, democratic practices, and a mentality of difference or tolerance inside and outside classrooms (Drissi, 2014).

Cochran-Smith et al. (2009) state, "We argue that teaching for social justice, or what we title 'good and just teaching,' reflects an essential purpose of teaching in a democratic society in which the teacher is an advocate for students whose work supports larger efforts for social change." The question of how to teach effectively from a clear social justice perspective that empowers and encourages students to think critically, and model social change has been a consistent challenge for progressive educators (Hackman, 2005).

The results of teaching will serve as basis for further research. This will lead to a rational program development and contribute to increasing output per the CNU's mandate, agenda, strategic directions and/or goals. This supports Forman's (1903) claim that states, "To train for good citizenship - which, we are told in season and out of season, is the chief function of the school-is therefore, a most ambitious task." It has become increasingly common for education scholars to claim a social justice orientation in their work. At the same time, education programs seem to be adding statements about the importance of social justice to their mission, and a growing number of teacher education programs are fundamentally oriented around a vision of social justice. Despite all the talk about social justice, it is often unclear in any practical terms what one means when he or she invokes a vision of social justice or how this influences such issues as program development, curricula, practicum opportunities, educational philosophy, social vision, and activist work (Hytten \& Bettez, 2011).

\subsection{Program development contribution to increasing output per the CNU's mandate, agenda, strategic directions, and goals}

The Position Classification and Compensation Scheme for Faculty Positions covers all teaching positions involved in instruction, research, and extension activities in all all-State Universities and Colleges, Commission on Higher Education-Supervised Higher Education Institutions and Technical Education and Skills Development Authority Supervised Technical Education Institutions (Department of Budget and Management). It is recommended that results of this research-based outreach extension program will serve as the basis for an intensive program amid the fourfold functions of a professor encompassing hybrid initiative about social justice advocacy.

The publicly funded higher education institutions, especially the state universities and colleges, which were made more capable and accountable to the state through enhanced public investments, are the main instruments in developing high-level professionals to meet the 
manpower needs of industry, public service, and civil society. Through their triad of functions, namely instruction, research, and extension, SUCs significantly contribute to the urgent tasks of alleviating poverty, hastening the pace of innovations, creating new knowledge and functional skills, and increasing the productivity of the workplace and the dynamism of communities (Republic of the Philippines, 2013).

Universities increasingly cast themselves as engaged institutions committed to building collaborative relationships with community-based stakeholders (Dempsey, 2010). Divergent paradigms operate in SUCs, which influence the performance of extension projects toward attainment of full empowerment as the ultimate goal implied by the universally accepted definition of community development (Ontoy \& Paspasan, 2016).

The Cebu Normal University's vision is to become, "A leading multidisciplinary research university of education committed to build a strong nation" and its mission to develop highperforming professionals and intellectuals proficient in generating new knowledge toward a progressive and peaceful pluralistic society. The University pursues five strategic directions for 2017 through various innovations and initiatives. To sustain quality and relevance, the following programs and activities will be pursued: (1) Blended Instruction, (2) Faculty and Student Exchange Programs, (3) Streamlining of Processes, (4) Internationally Based Faculty and Staff Development, (5) Strong Industry and Academe Interface, (6) Student Mobility Program; and (7) Pursuit of Quality Assurance Mechanisms (Cebu Normal University, n.d.).

Kaangayan as an outreach-extension program about social justice contributes to increasing output in line with the Cebu Normal University's thrust to sustain its tradition of excellence and cultivate significance and in answer to its mandate to contribute to nation building, the delivery of quality higher and advanced higher education, significant contribution to knowledge generation in the nation and relevant extension services to the community are facilitated by excellent resource management and a healthy fiscal condition. Acknowledging its vital role in nation-building through contributing to the development of human capital in the country, CNU functions to provide broad and general and highly specialized education that assists each learner to attain his or her full potential as a human being, enhance the range and quality of his or her participation in the basic functions of society and acquire the essential educational foundation for his or her development into productive and versatile citizens. CNU's academic programs, research institutes and comprehensive extension activities provide leadership necessary for the advancement of knowledge in the country and improvement of the lives of the quality of life of the Filipino (Cebu Normal University, n.d.). 
Approved on April 24, 2010 through BOR Resolution No. 13, s. 2010, Cebu Normal University has to expand community engagement and linkages, the following programs and activities will be pursued, (1) Strengthening of partnerships with international and national agencies, (2) Expansion of needs-based extension projects, (3) Generation of externally-funded extension projects, and (4) Pursuit of policy development initiatives for internationalization (Cebu Normal University, 2010). Likewise, the CNU Mission comprises three mutually reinforcing thrusts in (1) transformative education that nurtures thinking individuals who are valued members and leaders of society; (2) high impact researches that push the boundaries of knowledge in education and contribute to improving communities; and (3) strong partnership that collectively and creatively addresses the development gaps of communities (Cebu Normal University, n.d.). Therefore, it is a must that all extension initiatives on program development should address the aforementioned policy statements.

\section{Methods}

This research employed the pure "fishbowls" qualitative method of data collection according to the turnout from the invitation extended to the participants last September 30, 2017 in one of the barangays in Cebu being an adopted community of Cebu Normal University up to the current times. The invitation attracted 150 attendees. The outreach extension program was rated using the technical training evaluation as prescribed by the CNU Extension Manual. Based on the concluded activity, the technical/completion report was then prepared and submitted to the Office of Extension Services. Thereafter, all data were consolidated, processed, saturated, and finalized toward the qualitative results on policy analysis based on the technical/completion of outreach extension project and the results of the training technical evaluation.

Fishbowls are useful for ventilating "hot topics" or sharing ideas or information from a variety of perspectives. When the people in focus are public officials or other decision-makers, this technique can help bring transparency to the decision-making process and increase trust and understanding of complex issues (Better Evaluation, 2019).

In the details by which this outreach-extension was conducted, it underwent three phases namely, (1) The Conceptualization and Planning Stage where the proponents prepared the blueprint and presentation of the extension proposal for university approval along with the budget release on fiscal administration. Upon consent, letters on permission were channelled to the University Officials with the Academic and Extension Chairmen of the Department of Public Governance and the Institute as focal then coursed through the Office of Extension and 
International Linkages through the Director's leadership with permission of the College of Arts and Sciences Dean then directed for endorsement to the Office of the Vice-President which was finally approved by the Office of the University President the "Authority to Conduct" to the community the initiative. Once all resources were exhausted including all the materials used for extension were procured, fore sighting the outreach-extension program through the creation of committees in-charge on what "ought" to be done commenced on deliberation and approval from the Council headed by the Chairman of the Barangay to invite all participants and necessary stakeholders; (2) The Implementation Stage continued on execution the actual outreach-extension program as planned. The proponents and the committees in-charge prepared the invitation, materials, transportation, food and the venue to hold the social justice forum and/or activity that was participated by the members of the community; (3) The Feedback and Evaluation Stage commenced where all partakers deliberately rated all the forms to conclude the said program as per stipulated above.

The derivation of all data that emanated from the community is guided by The Republic Act No. 10173, otherwise known as the Data Privacy Act, is a law that seeks to protect all forms of information, be it private, personal, or sensitive. It is meant to cover both natural and juridical persons involved in the processing of personal information. The participants' demographic profile and other information were left undisclosed for their protection and undue influence from any interference thereof.

\section{Results and discussion}

In the past two decades, many countries have seen a shift from a managerial or top-down approach toward a revitalized emphasis on building institutional bridges between government leaders and the citizenry, often termed "community engagement" (Head, 2007). As modified by the authors of the International Association of Public Participation, the Community Engagement Continuum as cited by (McCloskey, McDonald, \& Cook, 2013), the increasing level of community involvement, impact, trust, and communication flow at the onset exhibits an outreach that encompasses (1) some community involvement; (2) communication flow between communities; (3) coexisting entities, and; (4) optimized communication channels for outreach. The paradigm model vis-à-vis social justice on community engagement was established primarily on an outreach extension program. In recent years, the study of political participation has benefited from the growing attention on the study of social networks.

Historically, most explanations for political participation have focused on characteristics of individuals. Focusing on individuals makes it easy to know who the participants are; 
nevertheless, incorporating social networks deepens our understanding of the factors that lead people to express voice in the democratic process. Although the literature on participation has long been split between scholars who favor a focus on individuals and others who emphasize social networks, the two approaches complement one another. The individualistic factors known to correlate with participation, including education, religious attendance, political knowledge, political conviction, and civic duty all have a social dimension (Campbell, 2013).

The Increasing Level of Community Involvement, Impact, Trust, and Communication Flow at the onset exhibits Outreach that encompasses
a. Some Community Involvement;
b. Communication flows from one to another, to inform;
c. Entities coexist; and
d. Outcomes.

Optimally establishes communication channels for outreach as cited by McCloskey, McDonald, \& Cook (2013) correlates with the results of extension program's technical report as manifested in promoting social justice to the constituents, to wit:

a. The participants' turnout of 150 reveals Some Community Involvement as they attended the call to join the civic activity under Table 1;

b. The call per se to join the civic movement in one setting allowed the constituents to participate discussions relevant to social justice as the main theme of civic engagement wherein there is Communication to inform under Table 2;

c. The extension program involved all stakeholders to mention the university through channels all the officials as initiated by the Department and the Research Institute of Public Governance, the barangay local government units and all other stakeholders and their leaders plus the speakers and the rest of the service providers and the community itself which exemplifies the existence and/or co-existence of entities that completed the activity; and

d. The Outcomes: Optimally establishes communication channels for outreach as exemplified under Table 3. The Qualitative Results on Policy Analysis vis-à-vis Technical/Completion of Outreach-Extension Project and Results of the Training Technical Evaluation wherein the consequential outcomes are proven to have been aligned to the EXCERPT PROVISIONS FROM THE CEBU NORMAL UNIVERSITY MANUAL that serves as an opportunity for establishing more conduits that will promote social justice and design more outreach-extension programs that will help the 
community widen more dissemination and heighten awareness and participation on all government civic programs that will benefit them.

The current condition limits face-to-face research about community engagement due to the COVID-19 worldwide phenomenon and crisis that affected the small-medium-to-large communities in the Philippines. The strength and novelty of this paper is "rooted" upon the need for a research "continuum" about social justice along the pandemic that shall sustain research for extension to thrive and survive in recent times.

\subsection{Kaangayan social justice as an outreach extension program: The community involvement}

As previously stated, political participation is important in improving cooperation among participants. This can be applied to the community, especially in the barangay level as the main setting of this research-based outreach extension program about social justice.

Under Table 1, Sector (Purok) J and I with 22 and 20 respectively, had the highest turnout upon invitation while 10 from Sectors A and B were undisputedly the lowest. Using the fishbowl technique, this may mean that dissemination of information may have been high in Sectors I and J. On the other hand, participation depends on the cooperation among the community concerned based on the call from the barangay leaders. Although Sector B turned out to be the lowest due to non-attendance, Sector A participants were only a few as they included only the barangay Health Workers (BHWs). The BHWs ratio per the constituents remained small since they are the barangay service providers. The government limits the number of workers per the constituents' standard ratio. This is in line with the barangay's limited budget from the government and other sources.

Table 1. Participants' Turnout vis-à-vis the Conduct of Outreach Extension Program on Site

\begin{tabular}{ccc}
\hline Purok (Barangay Zone) & Participants & Type of Participants \\
\hline A & 10 & Barangay Health Workers \\
B & 10 & Barangay Constituents \\
C & 14 & Barangay Elected Leaders \\
D & 11 & Barangay Heads/Tanods \\
E & 18 & Barangay Constituents \\
F & 12 & Barangay Constituents
\end{tabular}




\begin{tabular}{ccc}
\hline Purok (Barangay Zone) & Participants & Type of Participants \\
\hline G & 15 & Barangay Constituents \\
H & 18 & Barangay Civic Leaders \\
I & 20 & Barangay Constituents \\
\hline J & 22 & Barangay Civic Leaders and \\
& & Constituents \\
\hline
\end{tabular}

Participatory governance seeks to deepen citizen participation in the governmental process by examining the assumptions and practices of the traditional view that generally hinders the realization of a genuine participatory democracy (Fischer, 2012). The research paradigm manifests the preparation of the Technical Report that encapsulates the feedback from the community and their support in the completion of the program. The preparation allows people in the community to cascade how social justice comes to play in the realization of government programs that are for the people. This, in fact, is participatory governance as reflected in the modified technical/completion Kaangayan report.

This encouraged community involvement and allowed local exchanges on social justice advocacy among the 150 participants, clearly showing their eagerness to attend the outreach. This was evident in the community training on civic engagement, whose rationale objective was to heighten the awareness of the barangay constituency. The methodologies that were utilized within community were diversified. They included exposition, corporativism, group discussions, deduction-induction, reportorial, and case studies to create a connection with the members of the community. Such connection encourages the community members to share their thoughts about social justice with the objectives at hand.

The resource persons were chosen based on their technical expertise, experience, and specialization to enable them effectively to interact with people from diverse backgrounds and age brackets. This contributed to establishing a rapport between the resource persons and the community members, resulting in civic engagement where the people's opinions, beliefs and ideas were respected. Thus, advancing their knowledge on civic education and their engagement in government and social justice.

The public education workshop was designed carefully to address people's needs based on the matrix above. It is carefully designed for social justice and the people's participation in the advocacy program. However, being an exercise conducted solely by the CNU, the advocacy program would have limitations. Nevertheless, the research produced positive results as evidenced by the community's acceptance and participation in the program. With the 
community's response to the training, the CNUs process and challenges could be improved upon and replicated on a larger scale to benefit other communities.

This technical completion report was prepared in line with the conduct of the extensionoutreach program about social justice whereby 150 constituents participated from the locality. This engenders the process by which the outreach program was implemented on the ground towards its realization. Its results were submitted to the university's extension office with the results in line the constituencies' evaluation as to the conduct of the program on social justice.

Participatory governance, as a subset of governance theory, emphasizes democratic practices. Grounded in the theory of participatory democracy, more generally, it offers a theory and practice of public engagement through deliberative processes. Advanced largely as a response to a democratic deficit in contemporary political systems, it extends the citizens' role beyond that of voters or watchdogs to include direct deliberative involvement with pressing policy issues (Hirsch \& Shulman, 1976). The diverse participation of all citizens of all ages exemplifies social justice as part of their lives in different aspects to empower them to express their support to the government for as long as there are avenues for them to be informed about the process, systems, and programs that will benefit the society's common good. All barangay constituencies participated and rated the outreach extension program "agree to strongly agree;" this clearly shows that communication was established, thereby increasing the social justice advocacy based on their feedback from the program's training evaluation. Thus, community involvement and clear channels of communication contributed to the participants' ability to understand social justice advocacy.

The turnout of 150 participants supports McCloskey, McDonald, \& Cook (2013) theory on community engagement on outreach extension as it relates to social justice where there is some community involvement, since the invitation is based on the influence of the leaders in the community. The sense of participation and camaraderie among the people in the community only showed cohesion among them in their eagerness to participate in the program. Community involvement is about civic participation among the members of the community. Despite their other priorities, they managed to set other activities aside and engage with each other. Considering the data, this is a clear manifestation of democracy wherein people assemble to discuss social justice through community engagement. Thus, participatory governance evidently works when people come together for a common purpose and bond with the interaction of leaders and their constituents for the good of all in a democracy. 
Table 2. The Result of the Outreach-Extension Program's Technical Training Evaluation

\begin{tabular}{|c|c|c|c|}
\hline Part & Training component & $\begin{array}{l}\text { Participants' rating } \\
\text { (by the average result) }\end{array}$ & Interpretation \\
\hline $\mathrm{I}$ & Content & 4.5 & Agree to strongly agree \\
\hline II & $\begin{array}{l}\text { Development of } \\
\text { knowledge }\end{array}$ & 4.8 & Agree to strongly agree \\
\hline III & $\begin{array}{c}\text { Learning } \\
\text { materials/equipment }\end{array}$ & 4.3 & Agree to strongly agree \\
\hline IV & Trainer & 5.0 & Strongly agree \\
\hline $\mathrm{V}$ & Methods of teaching & 4.7 & Agree to strongly agree \\
\hline Overall & & 4.66 & Agree to strongly agree \\
\hline $\begin{array}{l}\text { 5: Strongly Agree } \\
\text { 4: Agree } \\
\text { 3: Seldom Agree }\end{array}$ & $\begin{array}{l}\text { 2: Disagree } \\
\text { 1: Strongly Disagree } \\
\text { NA: Not Applicable }\end{array}$ & & \\
\hline
\end{tabular}

Based on Table 2, the outreach extension program yielded a 5.0 average for the training component and an average of 4.3 for the learning materials used in the activity on site as rated by the participants. The overall rating was 4.66; this included the trainers' expertise, qualification, and experience, meaning that the participants learned from the advocacy program. The 4.3 average for the learning materials was because the materials and equipment that were utilized in the activity had undergone bidding following the government regulation on procurement under (R.A.) 9184, otherwise known as the "Government Procurement Reform Act," for the purpose of prescribing the necessary rules and regulations for the modernization, standardization, and regulation of the procurement activities of the Government of the Philippines.

Villamejor-Mendoza (2015) advocated that government programs should strengthen the capacity of government institutions to link respective budgets with performance outcomes and enable citizens and civil society to monitor and evaluate them. This requires wise spending of government funds. The materials and equipment were a by-product of "prudence" to ensure that all that were used, no matter how inexpensive were still useful in enhancing the participants' learning in the advocacy program. The advocacy program was generally successful due to the proper coordination and cooperation among all the stakeholders concerned. The trainers' expertise enabled the constituencies in the locality to imbibe the principles of social justice. The right combination of resources would yield positive outcomes 
that facilitate the application of social justice into the lives of community members. This holds true for McCloskey, who believes that when communication flows between parties, they are better informed and educated (McCloskey, McDonald, \& Cook, 2013).

Such education serves as a reminder for all to support government programs while practicing social justice for the betterment of all. It also demonstrates that citizenship training is vital for the nation's progress both on the micro-and-macro levels of governance. In other words, the awareness and observance of social justice in individuals' daily lives is crucial for the promotion of community participation and support for community-based government program. This means that social justice, which encompasses the rule of law, should be reflected in the daily lives of community members. When all stakeholders collaborate, it can bring the community together, establish cooperation, achieve trust, respect, cooperation, camaraderie, and solidarity among community members.

The qualitative results on policy analysis based on the technical/completion report of outreach extension program and results of the training technical evaluation show that the social justice advocacy aligned its initiative and has complied with the CNUs extension mandate. The technical/completion report of the outreach extension program embodies social justice advocacy vis-à-vis the participants' high rating of 4.66, which positively implies the program's acceptability thereby cascading to the alignment and compliance of the university's extension mandate. The Extension's Qualitative Results on policy analysis resulted in the community's involvement and civic participation toward generating knowledge about social justice that led to the community's satisfaction as indicated in the technical/completion report as stated below.

This is an opportunity for this extension program about social justice in line with McCloskey's theory on community participation regarding Outcomes: Optimally Establishes Communication Channels for Outreach. It means that the members of the community are proactive to express their issues and concerns in the government for it to be "acted upon" by the government to establish connections of which the help people. The channelling of communication is very important, but it has to be aligned with the university's priorities in order for it to design more extension programs and initiatives that are significantly important for the people.

Because the qualitative results are aligned, it is therefore pertinent for the university to technically design more programs for the people in the community that will help them accordingly. In line with the university's mandate, the university's vision, mission and goals, the extension services goals, and objectives, guiding principles, and the extension strategies were aligned and complied with. This implies that all entities co-exist as supported by the 
community involved in communication channels in relation to social justice advocacy; thus, the university should set up similar initiatives to further increase support to local communities in need of services, education, and training.

Table 3. The Qualitative Results on Policy Analysis vis-à-vis Technical/Completion of Outreach-Extension Project and Results of the Training Technical Evaluation

\begin{tabular}{|c|c|c|c|c|}
\hline $\begin{array}{c}\text { Excerpt Provisions from } \\
\text { the Cebu Normal } \\
\text { University Manual }\end{array}$ & $\begin{array}{c}\text { Program } \\
\text { Compliance }\end{array}$ & Basis & $\begin{array}{l}\text { Program } \\
\text { Alignment }\end{array}$ & Basis \\
\hline University Mandate & Complied & $\begin{array}{l}\text { Technical/ } \\
\text { Completion Report } \\
\text { (Part I-XV) }\end{array}$ & Aligned & $\begin{array}{l}\text { Technical } \\
\text { Training } \\
\text { Evaluation } \\
\text { (Average Rating } \\
\text { of 4.66) }\end{array}$ \\
\hline $\begin{array}{l}\text { The University's } \\
\text { Vision, Mission, Goals }\end{array}$ & Complied & $\begin{array}{l}\text { Technical/ } \\
\text { Completion Report } \\
\text { (Part I-XV) }\end{array}$ & Aligned & $\begin{array}{l}\text { Technical } \\
\text { Training } \\
\text { Evaluation } \\
\text { (Average Rating } \\
\text { of } 4.66 \text { ) }\end{array}$ \\
\hline $\begin{array}{l}\text { The Extension Services } \\
\text { Goals and Objectives }\end{array}$ & Complied & $\begin{array}{l}\text { Technical/ } \\
\text { Completion Report } \\
\text { (Part I-XV) }\end{array}$ & Aligned & $\begin{array}{l}\text { Technical } \\
\text { Training } \\
\text { Evaluation } \\
\text { (Average Rating } \\
\text { of } 4.66 \text { ) }\end{array}$ \\
\hline $\begin{array}{l}\text { Guiding Principles in } \\
\text { the Conduct of } \\
\text { Extension Services }\end{array}$ & Complied & $\begin{array}{l}\text { Technical/ } \\
\text { Completion Report } \\
\text { (Part I-XV) }\end{array}$ & Aligned & $\begin{array}{l}\text { Technical } \\
\text { Training } \\
\text { Evaluation } \\
\text { (Average Rating } \\
\text { of } 4.66 \text { ) }\end{array}$ \\
\hline $\begin{array}{l}\text { Extension Strategies } \\
\text { Employed in the } \\
\text { Implementation of the } \\
\text { Programs/Projects }\end{array}$ & Complied & $\begin{array}{l}\text { Technical/ } \\
\text { Completion Report } \\
\text { (Part I-XV) }\end{array}$ & Aligned & $\begin{array}{l}\text { Technical } \\
\text { Training } \\
\text { Evaluation } \\
\text { (Average Rating } \\
\text { of } 4.66 \text { ) }\end{array}$ \\
\hline
\end{tabular}

Complied: Program has met the University Mandate

Not Complied: Program has not met the University Mandate

Aligned: Program has satisfied the Community

Not Aligned: Program has not satisfied the Community

The program on implementation demonstrates a partnership between the university and the community with all stakeholders' support, particularly from the leaders. Community leaders develop civic capacity to respond to major community-wide problems with a high potential for 
controversy. An ever-present potential for conflict means that the spirit of cooperation can be quickly eroded. Capacity differs from micro versions of social capital. To be lasting, civic capacity needs an institutional foundation for interaction among elites and a "grassroots" base through which ordinary citizens are engaged (Stone, 2001).

The excerpt provisions on extension from the university were revealed to have been targeted as desired. The feedback from the community was noted as encapsulated in the observance of the provisions stipulated above, ensuing participation among the citizenry in the community with the notion that all policies were observed from the onset of planning and preparation until implementation toward people's evaluation of the advocacy program, which resulted in people's acceptability of the program. This manifests greater awareness that the program has contributed to the society as explained by the locality in its constituency. As such, civic engagement is an umbrella term used to describe the activities, which promote the bridging of communities with socially conscious thought and action.

According to Ehrlich, "Civic engagement means working to make a difference in the civic life of our communities and developing the combination of knowledge, skills, values, and motivation to make that difference. It means promoting the quality of life in a community, through both political and non-political processes (Hoekema \& Elrich, 2000).” Thomas Ehrlich goes onto to say that an "amorally and civically responsible individual recognizes himself or herself as a member of a larger social fabric and therefore considers social problems to be at least partly his or her own; such an individual is willing to see the moral and civic dimensions of issues, to make and justify informed moral and civic judgments, and to take action when appropriate (Hoekema \& Ehrlich, 2000).”

As previously indicated, the International Association of Public Participation, the Community Engagement Continuum as cited by McCloskey, McDonald, \& Cook (2013), the increasing level of community involvement, impact, trust, and communication flow at the onset exhibits outreach that encompasses (1) some community involvement; (2) communication flows from one to another, to inform; (3) coexisting entities; and (4) optimally established communication channels for outreach. Community engagement is established congruent to the tenets of community participation, fostering cooperation among the constituents that bring about this outreach extension program on social justice.

\section{Conclusion}

The community engagement outreach continuum cased on extension policies regarding social justice has validated the outreach-extension program of CNU to have been thriving, surviving 
and flourishing despite the COVID-19 limitation to comportment the extension services through research that will contribute to the increasing capacity of the University's output that is congruent to its vision, mission, agenda, strategic directions and goals. Using The Kaangayan report on the outreach extension program by the CNU demonstrated compliance with the mandate issued by the Philippine Government to universities to train and educate communities in areas that would promote community participation in governance.

The chosen field, social justice advocacy, was highly rated and accepted by the community, resulting in increased civic engagement, and understanding of social justice both in theory and practice. This implies that engendering learning about social justice advocacy in local communities is vital for nation-building; it enhances civic education, participation, and literacy. This initiative may be replicated and expanded to a wider audience not only in the area of social justice but also in other fields that are of local, national, and international concern.

\section{Acknowledgment}

The researchers sincerely acknowledge the support of the Cebu Normal University Community most especially to the University President Dr. Filomena T. Dayagbil, Dr. Daisy R. Palompon, the VPAA, Dr. Angeline M. Pogoy, the VP-REP, the Office of Extension Services and International Linkages headed by Director Naila Y. Beltran with Dr. Vinchita G. Quinto as Extension Chairman, the Research Office headed Dr. Laurence L. Garcia with Professor Marino A. Garcia as Research Chairman, the College of Arts and Sciences Dean Dr. Milagros M. Greif, the Department of Public Governance chaired by Dr. Glenn L. Velmonte with all the Faculty Members and the Research Institute of Public Governance, Cebu Technological University College of Management and Entrepreneurship, DYMR-Radyo Ng Bayan, the Heads of the Barangay and its Chairman and the stakeholders and participants on the extension site a and to all those that are left unmentioned.

\section{Funding}

The Cebu Normal University through the Office of Extension Services and International Linkages funded this Research-Based Extension Program.

\section{Declaration of Conflicting Interest}

There is no conflicting of interest for this manuscript.

\section{Author Contribution}


Gary B. Lapiz and Amelia Girly L. Aranas formulated the blueprint and brainstormed the framework of the research paper. Anabelle C. Lagrosas served as a consultant regarding community engagement being a mass media practitioner along with her expertise on law and civic participation. All of the proponents are involved from conception to data gathering, collection and organization to writing and editing until such output is produced towards completion.

\section{Short Biography}

Dr. Gary B. Lapiz, ORCID ID 0000-0002-3172-3172, is currently holding the rank of Professor IV as a Resident Faculty and/or Lecturer in both Undergraduate and Graduate Studies at the Department of Public Governance, College of Arts and Sciences of the Cebu Normal University Main Campus in Cebu City, Philippines. He finished his degrees in Public Administration from Baccalaureate, Masters and Doctorate along with his other notches in Political Science, General and Special Education including Social Studies from various Higher Education Institutions namely: Cebu Normal University, Cebu Technological University and Cebu Institute of Technology-University, all of which are from Cebu City, Philippines. His major research interests include Politics, Governance and Administration, Public Policy, Social Justice and Education.

Dr. Amelia Girly L. Aranas, ORCID ID 0000-0003-0485-3409, is currently holding the rank of Professor VI/Dean and/or Lecturer in both Undergraduate and Graduate Studies at the College of Management and Entrepreneurship of the Cebu Technological University Main Campus in Cebu City, Philippines. She finished her degrees in Public Administration from Baccalaureate, Masters and Doctorate along with her degrees in Political Science and Medical Technology from various Higher Education Institutions namely: Southwestern University, University of the Visayas, Cebu Technological University and Cebu Institute of TechnologyUniversity, all of which are from Cebu City, Philippines. Her major research interests include: Politics, Governance and Administration, Ethical Leadership and Solid Waste Management Advocacy.

Dr. Anabelle C. Lagrosas is currently the Radio Anchor of DYMR-Radyo Ng Bayan and a Guest Lecturer at the Cebu Technological University Main Campus in Cebu City, Philippines. She finished her degrees in Mass Communication and Law at the University of San Jose- 
Recoletos in Cebu City, Philippines. Her major interests as a practitioner include mass media, developmental communication and an extensionist advocate in governance.

\section{References}

Adler, R. P., \& Goggin, J. (2005). What Do We Mean By "Civic Engagement"? Journal of Transformative Education 3(3), 236-253. https://doi.org/10.1177/1541344605276792

Anderson, Jock \& Feder, Gershon. (2003). Rural Extension Services (Vol. 2976). World Bank Publications.

ASEAN Studies Centre. (2008). ASEAN Community: Unblocking the Roadblocks. ISEAS Publishing. https://doi.org/10.1355/9789812308443

Better Evaluation. (2019, November 19). Fishbowl Technique. https://www.betterevaluation.org/en/evaluation-options/fishbowltechnique

Campbell, D. E. (2013). Social networks and political participation. Annual Review of Political Science, 16, 33-48. https://doi.org/10.1146/annurev-polisci-033011-201728

Cassidy, C., Brunner, R., \& Webster, E. (2014). Teaching human rights? “All hell will break loose!" Education, Citizenship and Social Justice, 9(1), 19-33. https://doi.org/10.1177/1746197913475768

Cebu Normal University Manual on Extension Services and International Linkages. (2019, January 04). Cebu Normal University Osmeña Boulevard, Cebu City, Philippines. https://www.cnu.edu.ph/

Cebu Normal University. (2010). BOR Resolution No. 13, s. 2010. Cebu Normal University Osmeña Boulevard, Cebu City, Philippines. https://www.cnu.edu.ph/

Cebu Normal University. (n.d.). Vision-Mission. Cebu Normal University Osmeña Boulevard, Cebu City, Philippines. https://www.cnu.edu.ph/

Cochran-Smith, M., Shakman, K., Jong, C., Terrell, D. G., Barnatt, J., \& McQuillan, P. (2009). Good and just teaching: the case for social justice in teacher education. American Journal of Education, 115(3), 347-377.

https://www.journals.uchicago.edu/doi/10.1086/597493

Dempsey, S. E. (2010). Critiquing community engagement. Management Communication Quarterly, 24(3), 359-390. https://doi.org/10.1177/0893318909352247

Drissi, S. (2014). Citizenship education reconsidered in the era of democratic transition. Citizenship, Social and Economics Education, 13(2), 93-103. https://doi.org/10.2304/csee.2014.13.2.93 
El-Bassel, N., Gilbert, L., Hunt, T., Wu, E., Oga, E. A., Mukherjee, T. I., ... \& Rapkin, B. (2021). Using community engagement to implement evidence-based practices for opioid use disorder: A data-driven paradigm \& systems science approach. Drug and Alcohol Dependence, 222, 108675. https://doi.org/10.1016/j.drugalcdep.2021.108675

Fischer, F. (2012). Participatory Governance: From Theory To Practice. In The Oxford Handbook of Governance. https://doi.org/10.1093/oxfordhb/9780199560530.013.0032

Forman, S. E. (1903). The aim and scope of civics. The School Review 11(4), 288-294. https://doi.org/10.1086/434467

Freire, P. (1970). Pedagogy of the oppressed. New York: Herder and Herder.

Gupta, J., \& Vegelin, C. (2016). Sustainable development goals and inclusive development. International Environmental Agreements: Politics, Law and Economics, 16(3). https://doi.org/10.1007/s10784-016-9323-Z

Hackman, H. W. (2005). Five essential components for social justice education. Equity and Excellence in Education, 38(2), 103-109. https://doi.org/10.1080/10665680590935034

Head, B. W. (2007). Community engagement: Participation on whose terms? Australian Journal of Political Science, 42(3). https://doi.org/10.1080/10361140701513570

Heads of State/Government of the ASEAN. (2015, November). ASEAN Community Vision 2025. https://www.asean.org/wp-content/uploads/images/2015/November/aecpage/ASEAN-Community-Vision-2025.pdf

Henry, S. G. (2011). The tyranny of reality. Jama, 305(4), 338-339.

https://doi.org/10.1001/jama.2011.9

Hirsch, S., \& Shulman, L. C. (1976). Participatory governance. Social Work in Health Care, 1(4):433-46. https://doi.org/10.1300/j010v01n04_04

Hoekema, D. A., \& Ehrlich, T. (2000). Civic responsibility and higher education. Academe, 86(5), 79. https://doi.org/10.2307/40251931

Hur, M. H. (2006). Empowerment in terms of theoretical perspectives: exploring a typology of the process and components across disciplines. Journal of Community Psychology, 34(5), 523-540. https://doi.org/10.1002/jcop.20113

Hytten, K., \& Bettez, S. C. (2011). Understanding Education for Social Justice. Educational Foundations, 25(1-2), 7-24. https://eric.ed.gov/?id=EJ925898

Independent University, Bangladesh (IUB). (n.d.). Outreach, Extension and Continuing Education (OECE). http://www.iub.edu.bd 
Jennings, B., \& Dawson, A. (2015). Solidarity in the moral imagination of bioethics. Hastings Center Report, 45(5), 31-38. https://doi.org/10.1002/hast.490

Jennings, B. (2018). Solidarity and care as relational practices. Bioethics, 32(9), 553561. https://doi.org/10.1111/bioe.12510

Juwita, R. (2020). The Right to Education in the Era of the ASEAN Community. Asia Pacific Journal on Human Rights and the Law, 21(2). https://doi.org/10.1163/1571815821020002

Langhelle, O. (2000). Sustainable development and social justice: Expanding the rawlsian framework of global justice. White Horse Press Environmental Values, 9(3), 295-323. https://doi.org/10.3197/096327100129342074

Lapiz, G. (2016). Justice in the Philippine political and socio-economic environments. University of the Visayas - Journal of Research, 10(1), 99-104. https://core.ac.uk/download/pdf/230830759.pdf

Mason, K. (2014). Justice in building, building in justice: The reconstruction of intragenerational equity in framings of sustainability in the eco-building movement. White Horse Press Environmental Values, 23(1), 99-118, https://doi.org/10.3197/096327114X13851122269124

Maton, K. I. (2008). Empowering community settings: agents of individual development, community betterment, and positive social change. American Journal of Community Psychology, 41(1-2), 4-21. https://doi.org/10.1007/s10464-007-9148-6

McCloskey, D. J., McDonald, M. A., \& Cook. (2013). Community Engagement: Definitions and Organizing Concepts from the Literature. Principles of Community Engagement, 41. https://www.atsdr.cdc.gov/communityengagement/pdf/PCE_Report_Chapter_1_SHEF.p df

Miller, R. L., \& Shinn, M. (2005). Learning from communities: overcoming difficulties in dissemination of prevention and promotion efforts. American Journal of Community Psychology, 35(3-4), 169-183. https://doi.org/10.1007/s10464-005-3395-1

Minkler, M. (2004). Ethical challenges for the "outside" researcher in community-based participatory research. Health Education and Behavior 31(6), 684-697. https://doi.org/10.1177\%2F1090198104269566

Nilsson, J. E., \& Schmidt, C. K. (2005). Social justice advocacy among graduate student in counseling, an initial exploration. Journal of College Student Development 46(3), 267279. https://doi.org/10.1353/csd.2005.0030 
Office of the Vice-President for Research, Development and Extension Batangas State University. (n.d).

http://batstateu.edu.ph/sites/files/transparency_seal/

operations_manual/vprde_eso_operations_manual_part2.pdf

Ontoy, D. S., \& Paspasan, R. M. (2016). Community development and divergent forces in Philippine State Universities and Colleges: Developing a protocol in evaluating extension projects towards community empowerment. Asia Pacific Journal of Multidisciplinary Research, 4(4), 1-8. https://www.academia.edu/download/62081082/APJMR2016.4.4.2.0120200212-46893-wy0m9c.pdf

Persson, M. (2015). Education and political participation. British Journal of Political Science, 45(3), 689-703. https://doi.org/10.1017/S0007123413000409

Popescu, H. G. (2008). Knowledge society. Metalurgia International, 13(1), 37-41. https://doi.org/10.1057/978-1-137-34809-8_3

Quennerstedt, A. (2020). Educational aims of rights education in primary school-zooming in on teachers and pupils in two classes. Education 3-13, 48(5), 611-624. https://doi.org/10.1080/03004279.2019.1635629

Republic of the Philippines. (1994). Section 8 (RA 7722).

https://www.officialgazette.gov.ph/downloads/1994/05may/19940518-RA-07722-FVR.pdf

Republic of the Philippines. (2013). What is K to 12 program?. Official Gazette Government of Philippines.

https://www.officialgazette.gov.ph/k-

12/\#: :text=The\%20K\%20to\%2012\%20Program,prepare\%20graduates\%20for\%20terti ary\%20education $\% 2 \mathrm{C}$

Republic of the Philippines National Economic Development Authority. (2017). Philippine Development Plan 2017-2022. http://www.neda.gov.ph/philippine-development-plan2017-2022/

Republic of the Philippines Department of Budget and Management. (2012). Position Classification and Compensation Scheme for Faculty Positions in State Universities and Colleges. $\quad$ https://www.dbm.gov.ph/wp-content/uploads/2012/03/Manual-on-PCCChapter-7.pdf?fbclid=IwAR3t7xj-pMFk-L3xE1pdIP2wZGy8Thmltc8p6myDZ70 QhHpNUuy-Uq6q7os 
Republic of the Philippines. (2016, August 29). Implementing Rules and Regulations of Republic Act 9184. Official Gazette of Philippines.

https://www.officialgazette.gov.ph/2016/08/29/ implementing-rules-and-regulations-ofrepublic-act-no-9184/

Robinson, C., Phillips, L., \& Quennerstedt, A. (2020). Human rights education: developing a theoretical understanding of teachers' responsibilities. Educational Review, 72(2), 220241. https://doi.org/10.1080/00131911.2018.1495182

Roti Chakraborty Senior Officer Outreach, Extension and Continuing Education (OECE) Office of the Pro-Vice Chancellor Independent University, Bangladesh (IUB)

Riezanova, N. (2020). The concept of citizenship as the core of civic education. International Scientific Journal of Universities and Leadership, 9, 87-97. https://doi.org/10.31874/25206702-2020-9-1-87-97

Stone, C. N. (2001). Civic capacity and urban education. Urban Affairs Review, 36(5), 595619. https://doi.org/10.1177/10780870122185019

National Economic and Development Authority. (2017). Philippine Development Plan 20172022. Pasig City, Philippines: National Economic and Development Authority. https://socialprotection.org/discover/legal_policy_frameworks/philippine-developmentplan-2017-2022

National Economic and Development Authority Region 7. (2018). Central Visayas Regional Development Research Agenda 2017-2022. Cebu City, Philippines: National Economic and Development Authority Regional Office 7. National Economic and Development Authority Region 7.

http://www.neda7.net.ph/wordpress/wp-content/uploads/2019/04/NEDA-7-RDRA.pdf

Thompson, V. L. S., Ackermann, N., Bauer, K. L., Bowen, D. J., \& Goodman, M. S. (2021). Strategies of community engagement in research: Definitions and classifications. Translational Behavioral Medicine, 11(2). https://doi.org/10.1093/tbm/ibaa042

United Nations. (2020, July 07). \#Envision2030: 17 goals to transform the world for persons with disabilities. https://www.un.org/development/desa/disabilities/envision2030.html Villamejor-Mendoza, M.F. (2015, July 16-18). Policy Reforms to Improve the Quality of Public Services in the Philippines. https://ncpag.upd.edu.ph/wp-content/uploads/2015/11/The-Quality-of-Public-Servicesin-the-Philippines_Villamejor- Mendoza.pdf 
Wronka, J. (1994). Human Rights and Social Policy in the United States: An educational agenda for the 21st century. Journal of Moral Education, 23(3), 261-272. https://doi.org/10.1080/0305724940230304 